\title{
Postanowienia Ustawy z dnia 23 marca 2017 r. o kredycie hipotecznym oraz o nadzorze nad pośrednikami kredytu hipotecznego i agentami oraz rekomendacji S Komisji Nadzoru Finansowego a zapobieganie kryzysom bankowości hipotecznej
}

\section{Wprowadzenie}

Dnia 23 marca 2017 r. uchwalona została ustawa o kredycie hipotecznym oraz o nadzorze nad pośrednikami kredytu hipotecznego i agentami ${ }^{1}$. Ustawa ta wdraża postanowienia dyrektywy Parlamentu Europejskiego i Rady 2014/17/UE z dnia 4 lutego 2014 r. w sprawie konsumenckich umów o kredyt związanych z nieruchomościami mieszkalnymi i zmieniającej dyrektywy 2008/48/WE i 2013/36/UE oraz rozporządzenie (UE) nr 1093/2010². Choć implementująca dyrektywę ustawa zawiera przede wszystkim normy prawa prywatnego, dotyczące szczególnych wymogów przy zawieraniu kredytu hipotecznego, to jednak warto zwrócić uwagę na publicznoprawne rozwiązania unormowane w tej ustawie, bowiem związane są one $\mathrm{z}$ materią makroostrożnościową na rynku finansowym, a ze względu na jej wagę oraz wpływ na generowanie ryzyka systemowego i przyczynianie się do osiągania celu

\footnotetext{
${ }^{1}$ Dz.U. 2017, poz. 819, dalej „ustawa o kredycie hipotecznym”.

2 Dz.Urz. UE L 60 z 28 II 2014 r., s. 34, dalej „dyrektywa o kredycie hipotecznym”.
} 
stabilności finansowej zostały poddane precyzyjnej regulacji. To właśnie, jak słusznie podkreślono w uzasadnieniu do projektu ustawy, „[n]a rynku mieszkaniowych kredytów hipotecznych w Unii Europejskiej stwierdzono występowanie przypadków nieodpowiedzialnego udzielania i zaciągania kredytów oraz nieodpowiedzialnego zachowania uczestników tego rynku. Wskazano w szczególności: nieporównywalne, niepełne i niejasne materiały reklamowe, brak dokonywania odpowiedniej oceny adekwatności oferowanych produktów do potrzeb klienta oraz niewystarczającą weryfikację zdolności kredytowej klientów"3.3. Podjęto zatem decyzję o intensywniejszej regulacji tego fragmentu spraw rynku finansowego, poprzez poddanie go z jednej strony ściślejszemu nadzorowi krajowego nadzorcy, a z drugiej - rozbudowanie obowiązków informacyjnych przed zawarciem umowy i przy jej zawarciu, które realizowane są przez banki na rzecz klientów rynku bankowości hipotecznej.

Celem opracowania jest analiza postanowień ustawy o kredycie hipotecznym z punktu widzenia jej makroostrożnościowej, a więc przede wszystkim publicznoprawnej treści, dokonanie rekonstrukcji potencjalnie, hipotetycznie makroostrożnościowej, stabilnościowej (czyli przyczyniającej się do urzeczywistnienia stabilności finansowej) treści oraz ocena przyjętych w ustawie rozwiązań nadzorczych w zakresie pośredników kredytowych i agentów, oferujących kredyty związane z nieruchomościami mieszkalnymi. Zamierzeniem autorki jest także ustosunkowanie się do zagadnienia istotnego dla teorii prawa rynku finansowego, a polegającego na interferencji norm prawa prywatnego i publicznego z punktu widzenia ich makroostrożnościowej materii i w ramach polityki makroostrożnościowej dla realizacji celu przeciwdziałania kryzysom finansowym ${ }^{4}$. Można bowiem argumentować, że makroostrożnościowe treści ustawy o kredycie hipotecznym są funkcjonalnie powiązane z Ustawą z dnia 5 sierpnia 2015 r. o nadzorze makroostrożnościowym nad systemem finansowym i zarządzaniu kryzysowym $\mathrm{w}$ systemie finansowym ${ }^{5} \mathrm{w}$ zakresie, $\mathrm{w}$ jakim wadliwa regulacja,

${ }^{3} \mathrm{Z}$ uzasadnienia do projektu ustawy o kredycie hipotecznym: https://legislacja.rcl. gov.pl/docs//2/12286052/12355928/12355929/dokument224217.pdf (dostęp: 20 XI 2017).

${ }^{4}$ M. Fedorowicz, Normatywny wymiar polityki makroostrożnościowej - uwagi w świetle projektu ustawy o nadzorze makroostrożnościowym nad systemem finansowym, w: Perspektywy i wyzwania integracji europejskiej, pod red. K. Opolskiego, J. Górskiego, Warszawa 2014, s. 375-386.

5 Tekst jedn. Dz.U. 2017, poz. 1934, dalej „ustawa makroostrożnościowa”. 
czy wadliwie konstruowane umowy o kredyt hipoteczny mogą stać się źródłem ryzyka systemowego bądź zagrażać powstaniu lub generowaniu ryzyka systemowego ${ }^{6}$. Głównym celem ustawy makroostrożnościowej, zgodnie z jej art. 1 ust. 2, jest bowiem w szczególności wzmacnianie odporności systemu finansowego na wypadek materializacji ryzyka systemowego i wspieranie przez to długookresowego, zrównoważonego wzrostu gospodarczego kraju, a cel zarządzania kryzysowego określony został jako efektywna współpraca członków Komitetu Stabilności Finansowej, w tym koordynacja działań podmiotów reprezentowanych przez tych członków, na rzecz utrzymania lub przywrócenia stabilności systemu finansowego oraz wymiana informacji, opinii i ocen. Zamierzeniem badawczym realizowanym $w$ niniejszym opracowaniu jest również dokonanie zestawienia postanowień ustawy o kredycie hipotecznym z wybranymi zaleceniami rekomendacji $S$ dla oceny makroostrożnościowego charakteru i trafności przyjętych rozwiązań regulacyjnych za

${ }^{6} \mathrm{~W}$ ustawie o nadzorze makroostrożnościowym nie sformułowano definicji nadzoru makroostrożnościowego, definicji tej brak również w aktach prawa Unii Europejskiej (UE) dotyczących Europejskiego Systemu Nadzoru Finansowego. Powszechnie nadzór makroostrożnościowy określa się jako nadzór systemowy pełniony przez krajowych i unijnych nadzorców z punktu widzenia istnienia ryzyka systemowego, jakie generuje lub może generować grupa instytucji finansowych (a zatem nie tylko banki, gdyż zakres tego nadzoru jest szeroki, bowiem każdy podmiot finansowy, nawet pojedynczy, ale o systemowym znaczeniu, może generować ryzyko systemowe). W ustawie o nadzorze makroostrożnościowym, zgodnie z jej art. 4 pkt 15, mianem ryzyka systemowego określa się ryzyko zakłócenia $\mathrm{w}$ funkcjonowaniu systemu finansowego, które w razie jego materializacji zaburza działanie systemu finansowego i gospodarki narodowej jako całości, którego źródłem mogą być w szczególności tendencje związane $\mathrm{z}$ nadmierną dynamiką akcji kredytowej lub zadłużenia i związane $\mathrm{z}$ nimi nierównowagi $\mathrm{w}$ zakresie cen aktywów, niestabilne modele finansowania, rozkład ryzyka w systemie finansowym, powiązania pomiędzy instytucjami finansowymi lub nierównowagi makroekonomiczne i sektorowe. Szerzej na temat nadzoru makroostrożnościowego zob. C. Kosikowski, Nowe prawo rynku finansowego Unii Europejskiej, w: Prawo rynku finansowego. Doktryna, instytucje, praktyka, pod red. A. Jurkowskiej-Zeidler, M. Olszaka, Warszawa 2016, s. 32 i n.; A. Jurkowska-Zeidler, Prawo Unii bankowej, w: Prawo rynku finansowego..., s. 83 i n.; eadem, Nowe organy i instytucje bezpieczeństwa rynku finansowego Unii Europejskiej, w: Przyszłość Unii Europejskiej w świetle jej ustroju walutowego i finansowego, pod red. C. Kosikowskiego, Białystok 2013, s. 289 i n.; A. Zalcewicz, Zmiany struktury instytucjonalnej i koncepcji nadzoru nad jednolitym rynkiem finansowym UE, w: System finansów publicznych. Prawo finansowe wobec wyzwań XXI wieku, pod red. A. Dobaczewskiej, E. Juchniewicza, T. Sowińskiego, Warszawa 2010, s. 232; M. Fedorowicz, Nadzór nad rynkiem finansowym Unii Europejskiej, Warszawa 2013, s. 130 i n.; eadem, W sprawie przyszłej organizacji nadzoru makroostrożnościowego w Polsce, "Bezpieczny Bank” 2014, nr 4, s. 83-100. 
pomocą ustawy lub za pomocą krajowego soft law prawa bankowego, do którego należy rekomendacja $S^{7}$.

Przyjętą metodą badawczą w opracowaniu jest metoda dogmatycznoprawna.

\section{Ochrona klienta na rynku kredytów hipotecznych}

Celem ustawy o kredycie hipotecznym, a także implementowanej tą ustawą dyrektywy o kredycie hipotecznym jest zapewnienie wysokiego poziomu ochrony konsumentów, którzy zawierają umowy o kredyt związane z nieruchomościami ${ }^{8}$. Ustawodawca krajowy, w ślad za prawodawcą unijnym, przyjął określony kształt normatywny ochrony klienta właśnie na rynku kredytów hipotecznych ze względu na znaczenie tej materii dla stabilności finansowej Unii Europejskiej, wychodząc ze słusznego założenia, że materia ta może wykazywać znaczenie makroostrożnościowe, wpływać na stabilność finansową i prowadzić do zagrożeń systemowych przez generowanie ryzyka systemowego. Chodzi w tym przypadku o tzw. sytuacje pionowe, polegające na tym, że wadliwie konstruowane umowy mogą stać się źródłem załamania systemowego, a więc stanowić potencjalne źródło ryzyka systemowego w rozumieniu ustawy o nadzorze makroostrożnościowym ${ }^{9}$. Zależności te stały się przedmiotem uzasadnień pomocnym dla zrozumienia

7 https://www.knf.gov.pl/knf/pl/komponenty/img/Rekomendacja_S_18_ 06_2013_34880._34880.pdf (dostęp: 14 XI 2017); uchwała nr 148/2013 Komisji Nadzoru Finansowego z dnia 18 VI 2013 r. w sprawie wydania Rekomendacji S dotyczącej dobrych praktyk w zakresie zarządzania ekspozycjami kredytowymi zabezpieczonymi hipotecznie (dalej „rekomendacja S”). Natomiast w odniesieniu do ekspozycji kredytowych finansujących nieruchomości, które nie są zabezpieczone hipotecznie zob. rekomendację T: uchwała nr 59/2013 Komisji Nadzoru Finansowego z dnia 26 II 2013 r. w sprawie wydania Rekomendacji T dotyczącej dobrych praktyk w zakresie zarządzania ryzykiem detalicznych ekspozycji kredytowych: https://dziennikurzedowy.knf.gov.pl/ DU_KNF/2013/11/akt.pdf (dostęp: 15 XI 2017).

${ }^{8} \mathrm{~W}$ niniejszym opracowaniu pominięto zmiany wprowadzone na mocy ustawy o kredycie hipotecznym do ustawy o kredycie konsumenckim, doprecyzowujące niektóre jej przepisy, pod kątem zwiększenia porównywalności i transparentności ofert kredytodawców oraz wzmocnienia pozycji konsumenta na rynku kredytów konsumenckich.

${ }^{9}$ M. Fedorowicz, Prawne ujęcie nadzoru makroostrożnościowego w świetle krajowych projektów ustaw o nadzorze makroostrożnościowym nad systemem finansowym w ramach przedsejmowego etapu legislacyjnego, w: Prawo rynku finansowego..., s. 113-136. 
kryzysu na rynku kredytów hipotecznych subprime ${ }^{10}$. Fundamentalnym celem ustawy o kredycie hipotecznym jest zatem rozwój przejrzystego, skutecznego i konkurencyjnego rynku wewnętrznego, a metodą osiągnięcia tego celu jest zawieranie spójnych i uczciwych umów, a przede wszystkim dostarczanie klientom odpowiednich informacji i wyjaśnień na każdym etapie, co ma przyczynić się do eliminacji czy ograniczenia negatywnych skutków zjawiska, jakim jest asymetria informacyjna na rynku finansowym, charakterystyczna i zachodząca pomiędzy z jednej strony bankami jako profesjonalnymi uczestnikami rynku, a z drugiej klientami rynku usług bankowych.

Trzeba zatem zauważyć, że w skali makro celem ustawy o kredycie hipotecznym jest uporządkowanie zawierania kredytu hipotecznego, jako newralgicznej materii, która może rodzić ryzyko systemowe, jest to więc cel, który również przyczynia się do urzeczywistnienia stabilności finansowej w tym właśnie fragmencie rynku finansowego.

Ogólnie środki do osiągnięcia tego celu w zakresie wzmocnienia ochrony klienta na rynku finansowym, tu w odniesieniu do kredytów hipotecznych, są znane doktrynie prawa rynku finansowego i były już wcześniej wykorzystywane w odniesieniu do rynku kapitałowego, na mocy regulacji MiFID I, a obecnie MiFID II $^{11}$. Istnieje powszechna doktrynalna zgoda, że ochrona klienta rynku usług finansowych odbywa się przez rozrost obowiązków informacyjnych, realizowanych przez

${ }^{10}$ Zob. szerzej P. Frątczak, Umowy bankowe a stabilność finansowa, "Bezpieczny Bank” 2015, nr 4, s. 67-90.

${ }^{11}$ Zob. m.in. E. Rutkowska-Tomaszewska, P. Zawadzka, Zadania Komisji Nadzoru Finansowego a sytuacja prawna inwestora na rynku kapitałowym, „Prawo Bankowe” 2008, nr 5, s. 68 i n.; E. Rutkowska-Tomaszewska, Ochrona konsumenta na rynku ustug finansowych w prawie europejskim na przykładzie najnowszych dyrektyw unijnych, w: Prawo europejskie 5 lat doświadczeń w polskim prawie finansowym. Zjazd Katedri Zakładów Prawa Finansowego i Podatkowego, pod red. H. Litwińczuk, Warszawa 2010, s. 298 i n.; eadem, Obowiazki informacyjne firm inwestycyjnych świadczacych usługi w ramach działalności maklerskiej wobec klientów detalicznych, w: Regulacja MiFID - skutki prawne dla funkcjonowania rynku finansowego, pod red. E. Rutkowskiej-Tomaszewskiej, Wrocław 2014, s. 78-79, i cytowana tam literatura; A. Michór, Regulacje MiFID II w systemie regulacji rynków finansowych w UE, w: Perspektywy i wyzwania..., s. 355-364; M. Fedorowicz, Implementacja regulacji MiFID do polskiego prawa rynku finansowego - wybrane zagadnienia teoretyczne i praktyczne, w: Regulacja MiFID..., s. 11-27; zob. też M. Pacak, MiFID II a MiFID - czy zmiany coś zmienia?, w: Nowe koncepcje i regulacje nadzoru finansowego. Nadzór makrostabilnościowy. Nadzór bankowy SKOK. Instrumenty finansowe, pod red. W. Rogowskiego, Kraków-Warszawa 2014, s. 268 i n. 
instytucje finansowe na rzecz swoich klientów ${ }^{12}$. Jest to tzw. ochrona przez informację. W dobie inflacji przepisów prawnych na rynku finansowym uznać można, że właśnie w dziedzinie informacji, jej zrozumienia i zastosowania w praktyce przez klienta istnieją znaczne trudności ze względu na skomplikowanie materii będącej treścią informacji. Powoduje to, że informacja ta może nie pełnić swojej funkcji i tworzyć częste zjawisko asymetrii informacyjnej. Prawodawca unijny i ustawodawca krajowy skupili się zatem nie tylko na poszerzeniu obowiązków kredytodawcy i pośrednika kredytowego w zakresie informacji udzielanych przed zawarciem umowy o kredyt hipoteczny, ale również na takim ich uszczegółowieniu, aby tworzyły transparentny obraz normatywny dla klienta w związku z zawieraną umową o kredyt hipoteczny.

Wyjściowymi i fundamentalnymi dla ochrony klienta postanowieniami ustawy o kredycie hipotecznym, realizującymi zarazem cele makroostrożnościowe, są postanowienia dotyczące zakresu podmiotowego tej ustawy. W art. 5 przywoływanego aktu przewidziano, że działalność gospodarcza, której przedmiotem jest udzielanie lub dawanie przyrzeczenia udzielenia konsumentowi kredytu hipotecznego, może być wykonywana wyłącznie przez kredytodawców. Z kolei do grona kredytodawców ustawa zaliczyła wyłącznie: banki krajowe, oddziały banków zagranicznych, instytucje kredytowe, oddział instytucji kredytowej i spółdzielcze kasy oszczędnościowo-kredytowe, które w zakresie swojej działalności gospodarczej udzielają lub dają przyrzeczenie udzielenia konsumentowi kredytu hipotecznego. $Z$ kolei w art. 6 tej ustawy uregulowano, że kredyt hipoteczny może zostać udzielony wyłącznie w walucie lub indeksowany do waluty, w której konsument uzyskuje większość swoich dochodów lub posiada większość środków finansowych lub innych aktywów wycenianych w walucie udzielenia kredytu hipotecznego lub walucie, do której kredyt hipoteczny jest indeksowany. W rekomendacji S przybliżono, że „bank powinien udzielać klientom detalicznym kredytów zabezpieczonych hipotecznie wyłącznie w walucie, w jakiej uzyskują oni dochód, także w przypadku klientów o wysokich dochodach" (rekomendacja 6). Jak słusznie przybliża się w uzasadnieniu do projektu ustawy o kredycie hipotecznym,

${ }^{12}$ M.in. E. Rutkowska-Tomaszewska, op. cit., passim; T. Nieborak, Tworzenie i stosowanie prawa rynku finansowego a proces ekonomizacji prawa, Poznań 2016, passim; M. Fedorowicz, Szczegółowe regulacje dotyczace rynku kapitałowego UE z perspektywy nadzorczej (część Wprowadzenie do Komentarza, pkt 7), w: Prawo rynku kapitałowego, pod red. T. Sójki, Warszawa 2015, s. 85-106. 
brak art. 6 w ustawie oznaczałby, że zgodnie z rekomendacją banki, do których ma zastosowanie rekomendacja $S$, nie udzielałyby kredytów w walucie obcej konsumentom uzyskującym swoje dochody w złotych, co powodowałoby zaburzenia konkurencyjne wśród innych podmiotów udzielających kredytów hipotecznych, a zaliczanych do kredytodawców zgodnie $z$ art. 5 ustawy. Wprowadzenie tego rozwiązania do ustawy gwarantuje lepszy standard ochronny dla klientów i również bardziej wyważone zasady konkurencji między kredytodawcami. Tak ścisłe i słusznie restrykcyjne wyznaczenie kręgu kredytodawców związane jest $\mathrm{z}$ tym, aby działalność kredytowa w tym obszarze pozostawała pod silnym nadzorem Komisji Nadzoru Finansowego (KNF). Taki kształt postanowień ustawy o kredycie hipotecznym realizuje również cele ustawy makroostrożnościowej.

Fundamentalne obowiązki kredytodawców i pośredników kredytu hipotecznego oraz agentów przed zawarciem umowy unormowano w rozdziale II ustawy o kredycie hipotecznym. Do szczególnie ważnych jej postanowień z punktu widzenia ochrony klienta zaliczyć należy m.in.: (1) obowiązek podmiotów do umieszczania w reklamach dotyczących kredytu hipotecznego danych dotyczących całkowitego kosztu kredytu hipotecznego, w szczególności stopy oprocentowania, w sposób zwięzły, jednoznaczny, zrozumiały i widoczny (art. 7 ust. 2 ustawy o kredycie hipotecznym); (2) w przypadku kredytu hipotecznego w walucie obcej kredytodawca, pośrednik kredytu hipotecznego oraz agent $\mathrm{w}$ reklamach dotyczących tego kredytu podają w sposób zwięzły, jednoznaczny, zrozumiały i widoczny informację, że wahania kursu wymiany walut mogą mieć wpływ na całkowitą kwotę do zapłaty przez konsumenta, jak i o ryzyku zmiany stopy procentowej (art. 7 ust. 4 i 5 ustawy o kredycie hipotecznym); (3) przed zawarciem umowy o kredyt hipoteczny podmioty są obowiązane przekazać konsumentowi, na trwałym nośniku, zindywidualizowane informacje niezbędne do porównania kredytów hipotecznych dostępnych na rynku, oceny konsekwencji ich zaciągnięcia i podjęcia przez konsumenta świadomej decyzji dotyczącej zawarcia umowy o kredyt hipoteczny (art. 11 ust. 1 ustawy o kredycie hipotecznym); (4) decyzja kredytowa jest wiążąca dla kredytodawcy przez 14 dni (art. 14 ust. 6 ustawy o kredycie hipotecznym).

Z kolei wśród obowiązków nałożonych na kredytodawców przy zawarciu umowy o kredyt hipoteczny, uregulowanych w rozdziale IV ustawy o kredycie hipotecznym, należy zwrócić uwagę na art. 29, który 
stanowi lex specialis do art. 69 ust. 2 ustawy Prawo bankowe ${ }^{13}$ i określa minimalną oraz niezbywalną treść umowy o kredyt hipoteczny. Prokonsumenckie znaczenie ma również art. 42 ustawy o kredycie hipotecznym przewidujący dla konsumenta prawo do odstapienia, bez podania przyczyny, od umowy o kredyt hipoteczny w terminie 14 dni od dnia zawarcia tej umowy.

Niewątpliwie, prokonsumenckimi i stabilnościowymi postanowieniami są również ustawowe wymogi dotyczące rejestru pośredników kredytowych, do którego wpisywani są pośrednicy kredytu hipotecznego i agenci oraz pośrednicy kredytowi w rozumieniu art. 5 pkt 3 ustawy z dnia 12 maja 2011 r. o kredycie konsumenckim ${ }^{14}$. Zapewnieniu bezpieczeństwa klientom rynku usług bankowości hipotecznej służą również rozbudowane postanowienia ustawy o poddaniu pośredników i agentów hipotecznych nadzorowi KNF.

\section{Nadzór nad pośrednikami kredytu hipotecznego i agentami}

W ustawie o kredycie hipotecznym wprowadzono regulacje w zakresie nadzoru nad pośrednikami kredytu hipotecznego i ich agentami świadczącymi usługi związane $\mathrm{z}$ kredytem hipotecznym, uznając, że jest to materia na tyle istotna makroostrożnościowo i mogąca wykazywać wpływ na stabilność finansowa, iż zasadne jest wprowadzenie nadzoru nad działalnością pośredników kredytu hipotecznego i agentów - tym bardziej że wskazana materia oferowania kredytów związanych z nieruchomościami mieszkalnymi wymykała się dotąd precyzyjnej i spójnej regulacji.

Zgodnie z postanowieniami rozdziału X ustawy o kredycie hipotecznym nadzór ten sprawuje Komisja Nadzoru Finansowego, ale warto również podkreślić, że także Europejski Organ Nadzoru Bankowego (EBA), jako organ unijnego nadzoru mikroostrożnościowego, może realizować niektóre uprawnienia nadzorcze sensu largo, wydając wytyczne czy zalecenia dotyczące tego obszaru regulacji, które następnie mogą być uwzględniane przy wykonywaniu zadań nadzorczych przez KNF w związku z art. 133 ust. 1a ustawy Prawo bankowe. Zakresem przedmiotowym nadzoru KNF, zgodnie z art. 69 ustawy o kredycie hipotecznym, objęto działalność gospodarczą prowadzoną przez pośredników kredytu hipotecznego i agentów.

${ }^{13}$ Ustawa z dnia 29 VIII 1997 r. Prawo bankowe (tekst jedn. Dz.U. 2017, poz. 1876).

${ }^{14}$ Tekst jedn. Dz.U. 2016, poz. 1528 ze zm. 
Jakkolwiek ustawodawca w art. 69 ust. 2 tej ustawy przewidział, że celem nadzoru nad działalnością pośredników kredytu hipotecznego i agentów jest zapewnienie zgodności tej działalności z przepisami ustawy, to z punktu widzenia celów dyrektywy o kredytach hipotecznych należy zauważyć, że celem rekonstruowanym z preambuły do tej dyrektywy i celem wyartykułowanym w dyskusji doktrynalnej jest również przeciwdziałanie $\mathrm{w}$ ten sposób kryzysom, jakie mogłyby się pojawiać na rynku kredytów hipotecznych i zagrażać tym samym celowi stabilności finansowej. Wynika z tego, że rekonstruowane z regulacji unijnych i powstałe $\mathrm{w}$ dyskusji doktrynalnej cele tej ustawy dotykaja także celów makroostrożnościowych.

Do podstawowych kompetencji KNF w zakresie realizacji celów nadzoru można zaliczyć: (1) wydawanie zaleceń w zakresie zapewnienia zgodności działalności z przepisami ustawy oraz podjęcia środków koniecznych do zapobieżenia naruszeniom praw konsumentów wynikających z ustawy; (2) żądanie udzielenia pisemnych lub ustnych informacji oraz przekazania danych umożliwiających zapewnienie zgodności prowadzonej działalności pośrednictwa kredytu hipotecznego z przepisami ustawy. Wzorem regulacji kompetencji nadzorczych KNF przewidzianych w ustawie Prawo bankowe (rozdział XI) i w ślad za ustalonymi już poglądami doktryny na ten temat, które tu mają analogiczne zastosowanie, należy wskazać, że użycie sformułowania "zalecenia”, którym posługuje się ustawodawca krajowy, wbrew literalnej wykładni, ma zdecydowanie charakter nadzorczy ${ }^{15}$ i niestosowanie się do tych zaleceń wywierać może dla nadzorowanych negatywne skutki prawne w postaci nałożenia sankcji represyjnych, unormowanych w ustawie. Ani jednak zalecenia, ani tym bardziej żądanie dostarczenia informacji nie wymaga, zgodnie z brzmieniem art. 69 ust. 3 ustawy o kredycie hipotecznym, użycia formy decyzji administracyjnej ${ }^{16}$, bowiem forma ta została za-

${ }^{15}$ Uwagi na temat zaleceń KNF z art. 138 ust. 1 ustawy Prawo bankowe, które to uwagi znajdują analogiczne wykorzystanie ze względu na podobną stylizację przepisów także w niniejszych rozważaniach, zob. zwłaszcza K. Kohutek, Komentarz do art. 138 ust. 1 ustawy Prawo bankowe, w: Prawo bankowe. Komentarz, t. 2, pod red. A. Zolla, Kraków 2005, s. 502 i n.

${ }^{16}$ Wcześniej uwagi na temat zaleceń KNF w odniesieniu do rynku bankowego, które to uwagi znajdują zastosowanie, ze względu na podobną konstrukcję przepisów, także w niniejszych rozważaniach zob. zwłaszcza M. Olszak, Bankowe normy ostrożnościowe..., s. 251. Na marginesie omawianej problematyki trzeba jednak podkreślić, że analiza art. 11 ust. 2 pkt 20a i pkt 21 ustawy Prawo bankowe w zw. z art. 138 ust. 1 pkt 1a i pkt 2a ustawy Prawo bankowe po nowelizacjach nakazują uszczegółowienie, że zalecenia KNF w zakresie treści objętych art. 138 ust. 1 pkt 1a i pkt 2a wymagają formy decyzji 
rezerwowana dla środków nadzorczych z art. 69 ust. 4 tej ustawy. Jest jednak formą szczególnej, wiążącej interwencji nadzorczej KNF, która powinna podlegać realizacji przez podmioty nadzorowane, ze względu na stosunek nadzorczy występujący między KNF a podmiotami objętymi nadzorem w zakresie ustawy o kredycie hipotecznym i następczą możliwość stosowania sankcji. Już jednak w kolejnych postanowieniach ustawy przewidziano dla KNF kompetencję do zastosowania środków władczych, sankcji represyjnych, uporządkowanych w katalogu powstałym w dużym stopniu na wzór i podobieństwo katalogu środków sankcyjnych $\mathrm{z}$ art. 138 ust. 3 ustawy Prawo bankowe ${ }^{17}$. Na gruncie art. 69 ust. 4 ustawy o kredycie hipotecznym KNF może, w razie stwierdzenia, że podmioty nadzorowane nie wykonują zaleceń, już w drodze decyzji administracyjnej stosować środki nadzorcze sensu stricto: (1) nałożyć na osobę zarządzającą bezpośrednio odpowiedzialną za stwierdzone nieprawidłowości karę pieniężną $\mathrm{w}$ wysokości do trzykrotnego miesięcznego wynagrodzenia brutto tej osoby, wyliczonego na podstawie średniego wynagrodzenia brutto za ostatnie 3 miesiące przed nałożeniem kary; (2) nałożyć na ten podmiot karę pieniężną w wysokości do 500000 zł; (3) wystąpić do tego podmiotu z wnioskiem o odwołanie osoby zarządzającej; (4) zawiesić w czynnościach osobę zarządzająca, co polega na wyłączeniu jej z podejmowania decyzji w zakresie praw i obowiązków majątkowych tego podmiotu; (5) cofnać zezwolenie albo wykreślić z rejestru pośredników kredytowych - w przypadku agentów oraz powiązanych pośredników kredytu hipotecznego.

W odniesieniu do środka nadzorczego, jakim jest cofnięcie zezwolenia, swoboda nadzorcza jest ograniczona, bowiem KNF obowiązana jest stosować ten środek zawsze wtedy, gdy pośrednik kredytu hipotecznego, zgodnie z art. 74 ustawy o kredycie hipotecznym, zrzeka się zezwolenia lub nie prowadził działalności pośrednictwa kredytu hipotecznego przez

administracyjnej, wobec uwzględnienia tej właśnie formy w katalogu art. 11 ust. 2 ustawy Prawo bankowe. Uznać stąd należy, że pozostałe zalecenia KNF formułowane na mocy art. 138 ust. 1 ustawy Prawo bankowe nie mają formy decyzji administracyjnej. Oznacza to również, że w sprawach o znaczeniu stabilnościowym, makroostrożnościowym dla przeciwdziałania sytuacji generowania ryzyka systemowego wprowadzono możliwość wydania zaleceń KNF właśnie w formie decyzji administracyjnej. Trzeba także zauważyć, że $\mathrm{w}$ odniesieniu do spraw $\mathrm{z}$ art. 69 ust. 3 pkt 1 i pkt 2 ustawy o kredycie hipotecznym nigdzie w przepisach (ani w ustawie Prawo bankowe, ani w ustawie o nadzorze nad rynkiem finansowym) nie przewidziano formy decyzji administracyjnej.

${ }^{17}$ Szerzej zob. art. 138 ust. 3 ustawy Prawo bankowe. Na temat środków nadzorczych ad rem i ad personam w prawie bankowym por. m.in. K. Kohutek, op. cit., s. 501 i n. 
okres 6 miesięcy; uzyskał zezwolenie na podstawie fałszywych oświadczeń lub dokumentów lub w inny sposób niezgodny z przepisami ustawy; nie spełnia wymogów, na podstawie których zezwolenie zostało udzielone, oraz gdy rażąco lub uporczywie narusza przepisy ustawy. Oczywiście, ostatnia przesłanka w postaci "uporczywego i rażącego" naruszania przepisów ustawy o kredycie hipotecznym jest przesłanką ocenną i wypełnienie jej treścią należy do KNF. W przypadku wydania decyzji administracyjnej o cofnięciu zezwolenia KNF obowiązana jest niezwłocznie wykreślić podmiot z rejestru pośredników kredytowych. Zawinione zaniechania w tym zakresie moga, jak można twierdzić, generować odpowiedzialność odszkodowawczą po stronie KNF w razie spełnienia pozostałych przesłanek cywilistycznej odpowiedzialności odszkodowawczej ${ }^{18}$.

W ustawie przewiduje się, że w przypadku niezastosowania się przez adresatów do żądania KNF o przekazanie informacji, sankcjami podlegającymi zastosowaniu będą tylko następujące: (1) nałożenie na osobę zarządzającą bezpośrednio odpowiedzialną za stwierdzone nieprawidłowości kary pieniężnej w wysokości do trzykrotnego miesięcznego wynagrodzenia brutto tej osoby; (2) nałożenie na ten podmiot kary pieniężnej w wysokości do 500000 zł; (3) cofnięcie zezwolenia albo wykreślenie z rejestru pośredników kredytowych - w przypadku agentów oraz powiązanych pośredników kredytu hipotecznego. W każdym jednak przypadku, gdy KNF stwierdzi, że pośrednik kredytu hipotecznego lub agent wykonuje działalność z naruszeniem przepisów ustawy, może nałożyć na ten podmiot wszystkie sankcje uregulowane w art. 69 ust. 4. ustawy o kredycie hipotecznym.

Ponownie wzorem regulacji sankcji w ustawie Prawo bankowe można wskazać, że zaprezentowany w ustawie o kredycie hipotecznym układ sankcji wyraża pewną gradację ich stosowania, od najmniej dotkliwych aż po cofnięcie zezwolenia czy wykreślenie z rejestru agentów. To jednak KNF w ramach przysługującego jej uznania oraz dla realizacji jej zadań i kompetencji decyduje o kolejności użycia sankcji z katalogu,

${ }^{18}$ Szeroko nakreślone rozważania i uwagi w zakresie odpowiedzialności odszkodowawczej na gruncie ustawy Prawo bankowe stały się inspiracją dla budowania konstrukcji odpowiedzialności KNF w tym zakresie i, jak się wydaje, wcześniejsze ustalenia na ten temat odnoszące się do ustawy Prawo bankowe można i warto odpowiednio uwzględniać na gruncie analizowanej ustawy, por. interesujące uwagi: M. Spyra, Komentarz do art. 48c ustawy Prawo bankowe, w: Prawo bankowe..., s. 359; A. Adamek, Komentarz do art. 48 g ustawy Prawo bankowe, w: Prawo bankowe..., s. 367 i n.; zob. też M. Fedorowicz, Nadzór..., s. 426 i n. 
zgodnie z zaobserwowanym naruszeniem. Przykładowo, KNF przy ustaleniu wysokości kary pieniężnej ma obowiązek uwzględnić rodzaj i wagę naruszenia, uprzednie naruszenia przepisów ustawy przez osobę zarządzającą oraz jej sytuację finansową, a także rodzaj i wagę naruszenia oraz rozmiar prowadzonej działalności.

Wskazane sankcje mogą być $\mathrm{w}$ procesie stosowania prawa również kumulowane: sankcje podmiotowe (ad personam), przedmiotowe (ad rem), a także łączone ze sobą sankcje podmiotowo-przedmiotowe. Warto też podkreślić, że w wyniku zastosowanych sankcji umowy hipoteczne pozostają ważne, co stanowi odpowiednik zasady ochrony pewności obrotu gospodarczo-bankowego, wyrażonej w art. 138 ust. 7 ustawy Prawo bankowe. Warto podkreślić, że decyzje administracyjne w sprawach: wystąpienia do właściwego podmiotu z wnioskiem o odwołanie osoby zarządzającej, zawieszenia w czynnościach osoby zarządzającej i cofnięcia zezwolenia albo wykreślenia z rejestru pośredników kredytowych - są natychmiast wykonalne.

Cel makroostrożnościowy urzeczywistniany przez stosowanie sankcji wyraża się zwłaszcza przy ustalaniu kary pieniężnej z art. 69 ust. 4 pkt 2 ustawy o kredycie hipotecznym, bowiem KNF może opublikować na swojej stronie internetowej informację o sankcjach nałożonych na pośrednika kredytu hipotecznego lub agenta, chyba że ujawnienie takiej informacji stanowiłoby poważne zagrożenie dla stabilności rynków finansowych lub wyrządzałoby niewspółmierną szkodę temu pośrednikowi lub agentowi. Upublicznienie informacji o zastosowanych sankcjach pełni funkcję ostrzegawczą na rynku finansowym i zapewnia większą jawność działań nadzorczych i dostęp do nich obecnym lub hipotetycznym, przyszłym klientów.

Do regulacji kwestii nadzoru nad pośrednikami kredytowymi i agentami w Unii Europejskiej należy stosować znana, zwłaszcza z prawa bankowego UE, zasadę paszportu europejskiego, inaczej jednolitej licencji ${ }^{19}$, zgodnie z którą zezwolenie otrzymane od właściwych organów nadzoru państwa macierzystego na wykonywanie działalności pośrednictwa kredytów hipotecznych i działalności agentów pozostaje ważne i skuteczne także $w$ razie realizowania tej działalności w innych państwach członkowskich UE, które stają się wówczas państwami goszczącymi. Zasada ta, dotycząca szeroko rozumianego zagadnienia podejmowania

${ }^{19}$ Zob. m.in.: A. Jurkowska-Zeidler, Bezpieczeństwo finansowe w świetle prawa Unii Europejskiej, Warszawa 2008, s. 125 i n.; T. Nieborak, Aspekty prawne funkcjonowania rynku finansowego Unii Europejskiej, Warszawa 2008, passim. 
i prowadzenia działalności przez instytucje finansowe na rynku UE, została również odzwierciedlona w ustawie o kredycie hipotecznym (w jej rozdziale 9). Pośrednik czy agent, którzy mają zamiar prowadzić działalność na terytorium goszczącego państwa członkowskiego przez oddział lub transgranicznie, zawiadamiaja, w formie pisemnej, o tym zamiarze KNF, a następnie to KNF notyfikuje (zawiadamia) o tym właściwe organy nadzorcze goszczącego państwa członkowskiego w terminie miesiąca od dnia otrzymania zawiadomienia i jednocześnie powiadamia o tym zainteresowany podmiot.

Występuje również zależność odwrotna, bowiem pośrednik czy agent mający siedzibę w innym niż Polska państwie członkowskim UE jako państwie macierzystym, dopuszczony do wykonywania tej działalności i wpisany do właściwego rejestru w macierzystym państwie członkowskim, może notyfikować swojej macierzystej władzy nadzorczej zamiar podjęcia i prowadzenia takiej działalności w formie oddziału czy działalności transgranicznej w Polsce, a wówczas organy nadzoru państwa macierzystego notyfikują ten zamiar KNF. Komisja Nadzoru Finansowego przekazuje temu pośrednikowi informacje dotyczące dodatkowych warunków prowadzenia działalności pośrednictwa kredytu hipotecznego na terytorium Polski.

Rozwiązania powyższe oznaczają również konieczność zapewnienia nadzoru nad działalnością pochodzących z innych państw członkowskich pośredników czy agentów funkcjonujących w Polsce. Konsekwencją nadzorczą przyjętej zasady paszportu europejskiego jest działająca na całym rynku finansowym UE zasada nadzoru państwa macierzystego nad działalnością oddziału danej instytucji finansowej, kredytowej czy - w tym przypadku - pośrednika lub agenta ${ }^{20}$. Oczywiście, zasada ta nie jest absolutna i doznaje ograniczeń, a ponadto jest warunkowana zasadą współpracy nadzorczej między organami nadzoru państwa macierzystego i goszczącego, a w razie sporu między nimi, przed milczeniem organów chroni działalność mediacyjna i decyzyjna $\mathrm{EBA}^{21}$ jako organu nadzoru mikroostrożnościowego na

${ }^{20} \mathrm{O}$ zasadzie nadzoru państwa macierzystego nad oddziałem instytucji kredytowej zob. m.in.: A. Jurkowska-Zeidler, Bezpieczeństwo..., s. 89; T. Nieborak, Aspekty prawne..., s. 96 i n.; A. Michór, Swoboda przedsiębiorczości na rynku finansowym Unii Europejskiej, w: Instytucje prawnofinansowe w warunkach kryzysu gospodarczego, pod red. W. Miemiec, K. Sawickiej, Warszawa 2014, s. 656 i n.; M. Fedorowicz, Nadzór..., s. 195 i n.

${ }^{21}$ EBA jest organem, a nie urzędem; na ten temat szerzej zob. T. Nieborak, Decyzja jako szczególna forma działań podejmowanych przez Europejski Organ Nadzoru Bankowego, w: Prawo finansowe w warunkach członkostwa Polski w Unii Europejskiej. Ksiega jubileuszowa 
rynku bankowym, zgodnie z kompetencjami nadzorczymi wynikającymi z art. 19 rozporządzenia o EBA $^{22}$ w zw. z art. 70 ust. 5 ustawy o kredycie hipotecznym ${ }^{23}$.

W art. 70 tej ustawy przewidziano, że KNF ma obowiązek współpracy nadzorczej z właściwymi organami nadzorczymi odpowiednio macierzystego państwa członkowskiego albo goszczącego państwa członkowskiego, co wyraża się głównie w przekazywaniu właściwemu organowi nadzorczemu, na żądanie lub z własnej inicjatywy, informacji niezbędnych do osiągnięcia celów współpracy nadzorczej, zwłaszcza w zakresie przypadków stwierdzenia lub podejrzenia naruszenia prawa przez pośrednika kredytu hipotecznego lub agenta bądź jego oddział. Jak wiadomo, o sukcesie czynności nadzorczych w sytuacjach transgranicznych decyduje przede wszystkim dostęp do informacji nadzorczej i szybkość jej przepływu, a następnie właściwe nią zarządzanie. Dlatego dobrze uregulowano szeroki zakres podmiotowy współpracy nadzorczej, bowiem KNF może udzielać informacji uzyskanych w związku z wykonywaniem zadań wynikających z ustawy: (1) właściwym organom nadzorczym odpowiednio macierzystego państwa członkowskiego albo goszczącego państwa członkowskiego; (2) bankom centralnym państw członkowskich innych niż Polska, innym instytucjom państw członkowskich wykonującym zadania z zakresu polityki monetarnej oraz innym organom publicznym państw członkowskich innych niż Polska wykonującym zadania z zakresu nadzoru nad rynkiem finansowym; (3) organom i instytucjom Unii Europejskiej właściwym w zakresie spraw związanych z nadzorem nad kredytodawcami lub pośrednikami kredytu hipotecznego świadczącymi usługi związane z kredytem zabezpieczonym hipoteką. Brak tu jakkolwiek wyszczególnienia Komitetu Stabilności Finansowej (dalej KSF) jako krajowego organu nadzoru makroostrożnościowego, jednak ze względu na to, że KNF wchodzi w skład KSF, wiedza dotycząca ewentualnego ryzyka i zagrożeń mogących mieć znaczenie systemowe może w ten sposób stać się przedmiotem uwagi całego KSF.

dedykowana Profesor Wandzie Wójtowicz, pod red. A. Pomorskiej, P. Smolenia, J. Stelmasiaka, A. Gorgol, Lublin 2011, s. 322.

${ }^{22} \mathrm{O}$ charakterze prawnym decyzji EBA i pozostałych ESA (European Supervisory Authorities, Europejskich Organów Nadzoru Finansowego) zob. M. Fedorowicz, A. Michór, O charakterze prawnym decyzji nowych europejskich organów nadzoru nad rynkiem finansowym UE, "Europejski Przegląd Sądowy” 2011, nr 11, s. 24-35.

${ }^{23}$ Szerzej M. Fedorowicz, Nadzór..., s. 263 i n. 
Procedura stosowania środków nadzorczych, określona w art. 71 ustawy o kredycie hipotecznym, wobec pośredników czy agentów funkcjonujących w Polsce w formie oddziału czy działalności transgranicznej modyfikowana jest zasadą nadzoru państwa macierzystego. Wynika stąd, że zasadą jest, iż to organ nadzoru państwa macierzystego powinien stosować środki nadzorcze. W związku z tym $\mathrm{KNF}$, w razie stwierdzenia naruszeń z zakresu rozdziałów II-IV ustawy o kredycie hipotecznym (czyli w zakresie: obowiązków kredytodawcy, pośrednika kredytu hipotecznego i agenta przed zawarciem umowy o kredyt hipoteczny; świadczenia usług doradczych oraz umowy o kredyt hipoteczny), najpierw wzywa ten podmiot, $\mathrm{w}$ formie pisemnej, do przestrzegania przepisów prawa polskiego i wyznacza mu termin usunięcia stwierdzonych nieprawidłowości, a następnie po bezskutecznym upływie terminu wyznaczonego w wezwaniu obowiązany jest zawiadomić właściwe organy nadzorcze macierzystego państwa członkowskiego o stwierdzonych nieprawidłowościach. Zawinione zaniechania KNF w tym zakresie mogą skutkować odpowiedzialnością odszkodowawczą ${ }^{24}$. Dopiero w razie wystąpienia sytuacji nadzwyczajnej, w ramach której nadmierna zwłoka mogłaby zagrażać ważnym interesom konsumentów, a środki zastosowane przez organ władzy macierzystej nie usunęły naruszenia lub są nieadekwatne albo organ ten milczy, KNF może - i to odpowiednio - zastosować środki nadzorcze $\mathrm{z}$ katalogu ustawowego, jednak nie wszystkie, ale tylko wybrane. Należą do nich: (1) nałożenie na osobę zarządzającą bezpośrednio odpowiedzialną za stwierdzone nieprawidłowości kary pieniężnej w wysokości do trzykrotnego miesięcznego wynagrodzenia brutto tej osoby; (2) wystąpienie do tego podmiotu z wnioskiem o odwołanie osoby zarządzającej; (3) zawieszenie w czynnościach osoby zarządzającej. Komisja Nadzoru Finansowego obowiązana jest ponadto zawiadomić właściwe organy nadzorcze macierzystego państwa członkowskiego o stwierdzonych nieprawidłowościach i podjętych środkach, a także - co do zasady - Komisję Europejską. Komisja Nadzoru Finansowego, zgodnie z zasadą nadzoru państwa macierzystego, nie będzie mogła cofnąć zezwolenia na prowadzenie działalności przez

${ }^{24}$ Podobnie jak ma to miejsce na rynku bankowym w odniesieniu do zaniechań notyfikacyjnych organów nadzorczych. Problematykę tę można odnieść, ze względu na podobieństwa regulacyjne, również do odpowiednich postanowień ustawy o kredycie hipotecznym, w których unormowano obowiązki informacyjne KNF (zob. przypis 18). 
pośrednika czy agenta. Jednak gdy KNF jako organ nadzoru państwa macierzystego wydała decyzję administracyjną o cofnięciu zezwolenia, a pośrednik kredytu hipotecznego prowadzi działalność pośrednictwa kredytu hipotecznego na terytorium państw członkowskich innych niż Polska transgranicznie lub przez oddział, to obowiązana jest powiadomić o tym właściwe organy goszczących państw członkowskich w terminie 14 dni od dnia wydania tej decyzji. Także i w tym przypadku można argumentować, że zawinione zaniechania tego obowiązku notyfikacyjnego mogą w konkretnej sytuacji oznaczać możliwość dochodzenia odpowiedzialności odszkodowawczej od KNF (Skarbu Państwa), przy spełnieniu pozostałych cywilistycznych przesłanek tej odpowiedzialności.

Jak już wskazano, powyższe rozwiązania nadzorcze przewidziano dla pośredników i agentów prowadzących swoją działalność w Polsce jako państwie goszczącym w zakresie naruszeń postanowień rozdziałów II-IV ustawy o kredycie hipotecznym, natomiast w przypadku pozostałych mniejszych naruszeń prawa przewidziano uproszczony tryb postępowania nadzorczego. Zgodnie z art. 72 ustawy o kredycie hipotecznym KNF w przypadku stwierdzenia naruszeń także ma obowiązek zawiadomić organ nadzoru państwa macierzystego, nadal jednak po miesiącu milczenia nadzorcy macierzystego lub nieusunięcia nieprawidłowości może od razu zastosować odpowiednio wybrane środki nadzorcze, analogicznie jak w przypadku naruszeń rozdziałów II-IV ustawy o kredycie hipotecznym, zawiadamiając właściwe organy nadzorcze macierzystego państwa członkowskiego o podjętych środkach, także KE oraz EBA, lub przekazać sprawę do Europejskiego Organu Nadzoru Bankowego na podstawie art. 19 rozporządzenia o EBA.

W ramach funkcji kontrolnej KNF może również przeprowadzać kontrole działalności pośrednika kredytu hipotecznego lub agenta świadczącego usługi pośrednictwa kredytu hipotecznego. Czynności kontrolne obejmować mogą: wstęp do pomieszczeń kontrolowanego podmiotu; swobodny dostępu do oddzielnego pomieszczenia biurowego i środków łączności; wgląd do dokumentów kontrolowanego podmiotu oraz żądania sporządzenia kopii i odpisów tych dokumentów, wyciągów z nich oraz wglądu do danych zawartych w systemie informatycznym kontrolowanego podmiotu, żądania sporządzenia kopii tych danych lub wyciągów z nich, w tym w postaci dokumentów elektronicznych. 


\section{Rekomendacja S dotycząca dobrych praktyk w zakresie zarządzania ekspozycjami kredytowymi zabezpieczonymi hipotecznie jako miękki instrument służący przeciwdziałaniu kryzysom bankowości hipotecznej}

W ramach szeroko pojętej funkcji nadzorczej (oprócz kompetencji licencyjnych, kontrolnych i stricte nadzorczych) KNF może także realizować uprawnienia regulacyjne, które w odniesieniu do analizowanej problematyki znalazły swoją aktualizację w postaci rekomendacji S dotyczącej bankowości hipotecznej. Podstawą prawną wydania rekomendacji stał się art. 137 ust. 1 pkt 5 ustawy Prawo bankowe. Zgodnie z tym przepisem KNF może wydawać rekomendacje dotyczące dobrych praktyk ostrożnego i stabilnego zarządzania bankami ${ }^{25}$. Nie powielając w tym miejscu niezwykle żywej dyskusji, która była toczona przez przedstawicieli doktryny prawa rynku finansowego na temat charakteru prawnego m.in. rekomendacji $\mathrm{KNF}^{26}$, wskazać trzeba, że rekomendacje nie stanowią ani aktów prawa powszechnie wiążącego, ani wewnętrznie wiążącego, ale są jedynie źródłami krajowego soft law nadzorczego, jeśli zawierają normy ostrożnościowe, o funkcjonalnym charakterze ${ }^{27}$, niewiążącego prawnie, do których banki ze względu na autorytet KNF i jej możliwości decyzyjne będą się stosować. Rekomendacje służą wypracowaniu w bankach dobrych praktyk, właściwego ładu korporacyjnego i zalecają bankom określone praktyki oraz wzorcowe postępowanie, które pomóc mają w realizacji stabilnego zarządzania bankami. Oznacza to, że rekomendacje wskazuja, zalecają określony sposób działania banku

${ }^{25}$ Szeroko na temat zmian w art. 137 ustawy Prawo bankowe zob. M. Olszak, Regulacje systemu finansowego w Unii Europejskiej a Konstytucja Rzeczypospolitej Polskiej - wybrane zagadnienia, "Studia Europejskie” 2016, nr 4, s. 188 i n.

${ }^{26}$ Zob. zwłaszcza: E. Fojcik-Mastalska, Podustawowe źródła prawa bankowego po nowelizacji, „Prawo Bankowe” 2002, nr 4, s. 52 i n.; R. Kaszubski, Funkcjonalne źródła prawa bankowego publicznego, Zakamycze 2006, s. 46 i n.; C. Kosikowski, op. cit., s. 32; A. Jurkowska-Zeidler, Prawo Unii..., s. 84 i n.; D. Wojtczak-Samoraj, Soft law i mechanizmy nielegislacyjne jako instrumenty integracji rynku ustug bankowych Unii Europejskiej, „Monitor Prawa Bankowego" 2012, nr 1, s. 58 i n. Na temat norm ostrożnościowych, uchwał i rekomendacji KNF zob.: M. Olszak, Bankowe normy ostrożnościowe, Białystok 2011, s. 81, 94 i n.; idem, Zmiany dotychczasowych rozwiazań prawnych w zakresie nadzoru nad rynkiem finansowym Unii Europejskiej - wybrane problemy, w: Przyszłość Unii Europejskiej..., s. 263 i n.; C. Kosikowski, M. Olszak, Od prawa bankowego do prawa rynku finansowego, w: System prawa finansowego, t. 4: Prawo walutowe, prawo dewizowe, prawo rynku finansowego, pod red. J. Głuchowskiego, Warszawa 2010, s. 239.

${ }^{27}$ R. Kaszubski, op. cit., s. 32 i n. 
i są miękkimi instrumentami wspierającymi dobre praktyki ostrożnego i stabilnego zarządzania bankami.

W odniesieniu do rekomendacji S warto zauważyć, że stanowi ona zbiór zasad dotyczących dobrych praktyk w zakresie ekspozycji kredytowych zabezpieczonych hipotecznie, które zdecydowanie wykazują znaczenie makroostrożnościowe i stanowią jeden $\mathrm{z}$ regulacyjnych wniosków po globalnym kryzysie finansowym, dzięki któremu to wnioskowi ma nastąpić zniwelowanie nadmiernego rozluźnienia standardów kredytowych w obszarze kredytów mieszkaniowych i związanego z tym nadmiernego zadłużenia części gospodarstw domowych. Standardy rekomendacji S mają zastosowanie do wszystkich banków objętych przepisami prawa polskiego, jednak istotne jest to, że odrębnie banki ewaluują swoją politykę kredytową w odniesieniu do nieruchomości mieszkalnych, a odrębnie do nieruchomości komercyjnych. Biorąc pod uwagę zagrożenia dla ryzyka systemowego, w rekomendacji zalecono, by banki raz do roku określały swój poziom udziału w rynku. Szczególne zalecenia wyrażono w rekomendacji dla banków istotnie zaangażowanych, dla których udział portfela ekspozycji kredytowych zabezpieczonych hipotecznie przekracza $2 \%$ wartości ekspozycji kredytowych zabezpieczonych hipotecznie dla całego sektora bankowego w Polsce, co wynika z art. 51 ust. 1 lit. a) dyrektywy CRD IV, bowiem to właśnie te banki mogą mieć znaczenie systemowe i swoją działalnością tworzyć szczególne zagrożenia dla ryzyka systemowego.

Jednym z celów regulacyjnych tej rekomendacji jest zapewnienie wysokiej jakości portfeli kredytowych oferowanych przez banki, a poprzez to bezpieczny i długofalowo stabilny rozwój rynku instrumentów dłużnych opartych na jednorodnych portfelach kredytów mieszkaniowych, który ułatwia oszacowanie ryzyka i prowadzenie długofalowej działalności kredytowej na rynku hipotecznym, uwzględniającej również ryzyko systemowe, jeśli polityka udzielania tych kredytów realizuje podejście cykliczne. Ważne jest też, że w rekomendacji $S$ uwzględniono dotyczące kredytowania w walutach obcych zalecenia Europejskiej Rady ds. Ryzyka Systemowego, a także rekomendacje Narodowego Banku Polskiego oraz Bazylejskiego Komitetu ds. Nadzoru Bankowego. Stosowne treści rekomendacji S dotyczą w szczególności: (1) kredytów walutowych, długości maksymalnego okresu kredytowania, długości maksymalnego okresu branego na potrzeby wyliczania zdolności kredytowej czy też minimalnego wkładu własnego oraz klientów mających nieregularne lub niestabilne dochody; (2) identyfikacji, pomiaru i oceny 
ryzyka ekspozycji kredytowych zabezpieczonych hipotecznie, stosowanych zabezpieczeń; (3) monitorowania i raportowania w zakresie ryzyka ekspozycji kredytowych zabezpieczonych hipotecznie, jak i relacji z klientami. W części zatem rekomendacja ta uzupełnia i konkretyzuje postanowienia ustawy o kredycie hipotecznym. Jak wskazuje sama KNF w rekomendacji, zalecenia dla banków tam wyrażone stanowią „ramy dla poprawnej identyfikacji, nadzoru i zarządzania ryzykiem ekspozycji kredytowych zabezpieczonych hipotecznie; są zbiorem zaleceń w stosunku do wewnętrznych systemów kontroli, które pośrednio i bezpośrednio powinny zapewniać integrację rekomendacji w ramach wszystkich procesów związanych z ekspozycjami kredytowymi zabezpieczonymi hipotecznie" 28 .

Przykładowo, do najistotniejszych treści rekomendacji S należą: (1) rekomendacja 7 - zalecająca, aby bank rekomendował klientom detalicznym okres spłaty zobowiązań nie dłuższy niż 25 lat. W przypadku podjęcia przez klienta decyzji o dłuższym okresie spłaty bank nie powinien udzielić kredytu, którego okres spłaty przekraczałby 35 lat; (2) rekomendacja 8 - zalecająca rzetelną i kompleksową ocenę zdolności kredytowej klienta, uwzględniającą przedstawione źródła spłaty zobowiązania, koszty utrzymania typowe dla danego kredytobiorcy, wszystkie zobowiązania finansowe oraz ustalony okres kredytowania; (3) rekomendacja 10 - zalecająca, aby w przypadku ekspozycji związanej z finansowaniem nieruchomości bank nie kredytował pełnej wartości nieruchomości stanowiącej przedmiot zabezpieczenia; (4) rekomendacja 14 - zalecająca, aby bank monitorował wartość nieruchomości oraz ocenę faktycznej możliwości wykorzystania zabezpieczenia na danej nieruchomości jako ewentualnego źródła dochodzenia swoich roszczeń; (5) rekomendacja 22 - wskazująca, aby bank na bieżąco kontrolował, czy wszystkie warunki umowy są wypełniane przez klienta oraz czy środki finansowe wypłacane przez bank wykorzystywane są zgodnie z umowa; (6) rekomendacja 25 - zalecająca, by bank dokładał wszelkich starań i by przekazywane klientom informacje były zrozumiałe, jednoznaczne i czytelne, co dotyczy informacji przedstawianych zarówno przed, jak i po podpisaniu umowy. Istotne jest też, aby bank uwzględniał poziom wiedzy klienta.

Nie sposób oprzeć się wrażeniu, że zestawienie rekomendacji S z postanowieniami umowy o kredycie hipotecznym w zakresie informacji

\footnotetext{
${ }^{28}$ Rekomendacja S, s. 4.
} 
udzielanych klientom przed zawarciem umowy oraz w czasie jej realizacji pozwala przyjąć, iż treści rekomendacji S znalazły swoje normatywne zakorzenienie i uszczegółowienie w ustawie o kredycie hipotecznym ${ }^{29}$, co zdecydowanie służyć będzie ochronie klienta na rynku usług bankowości hipotecznej.

\section{Podsumowanie}

Treści ustawy o kredycie hipotecznym w części tzw. konsumenckiej, czyli dotyczącej ochrony klienta rynku usług bankowości hipotecznej, mimo że należą do norm prywatnoprawnych, realizują cel fundamentalny dla funkcjonowania rynku finansowego, tj. cel makroostrożnościowy, służący zapobieganiu powstawania ryzyka systemowego już na etapie podpisywania umów o kredyt hipoteczny, po to, aby w przyszłości niwelować wystąpienie falowych i długoterminowych problemów związanych z niewypłacalnością klientów, wahaniami kursu walutowego, które mogą przełożyć się na trudności instytucji kredytowej, całego sektora albo nawet systemu. Stanowi to zarazem argument za tym, że część postanowień ochronnych, konsumenckich w ustawie o kredycie hipotecznym realizuje również cele makroostrożnościowe z ustawy makroostrożnościowej, a zagadnienie ochrony klienta rynku usług bankowości hipotecznej stanowi także potencjalną materię makroostrożnościową czy też materię o funkcji makroostrożnościowej, istotną dla urzeczywistniania celu stabilności finansowej na rynku finansowym UE. Założeniem prawodawcy jest bowiem wyposażenie klienta w bardziej szczegółową i głęboką wiedzę na temat kredytu hipotecznego, stąd część konsumencka ustawy jest tak mocno rozbudowana i zawiera pewien minimalny standard dotyczący informacji przeznaczonych dla klientów, który może być poszerzany samoregulacyjnie przez banki. Dobrze stało się zatem, że treści, które dotąd były umieszczone w rekomendacji S, otrzymały tak mocne i głębokie ustawowe zakotwiczenie.

Pozytywnie ocenić należy również rozwiązania nadzorcze przewidziane ustawą o kredycie hipotecznym, a odnoszące się do kredytodawców, pośredników kredytowych i agentów. Regulacja nadzoru w ustawie o kredycie hipotecznym dokonana została na wzór i podobieństwo unormowań zawartych w ustawie Prawo bankowe, łącznie z zaprojektowanymi

${ }^{29}$ Zob. m.in. art. 10, 21 i 29 ustawy o kredycie hipotecznym. 
środkami nadzoru represyjnego. Postanowienia nadzorcze, niewątpliwie przynależące do obszaru norm publicznych, stanowić mają na gruncie tej ustawy system represyjny dla podmiotów działających niezgodnie z celami ustawy, które to cele - jak już stwierdzono - mogą również i powinny realizować makroostrożnościowe treści, gdyż luki w nadzorze nad działalnością podmiotów zajmujących się działalnością polegająca na udzielaniu kredytów hipotecznych mogą w konsekwencji powodować luki w tworzonym systemie makroostrożnościowych zapór i barier dla zniwelowania ryzyka systemowego i osiągania stanu długofalowej stabilności finansowej na rynku finansowym UE.

Na zakończenie warto również ustosunkować się do zagadnienia przyjętego sposobu regulacji spraw dotyczących ochrony klienta na rynku usług bankowości hipotecznej. Otóż okazuje się, że waga tego zagadnienia uznana została słusznie za tak dużą, iż wymagającą precyzyjnego i szczegółowego wyrażenia w ustawie o kredycie hipotecznym. Tym samym można zauważyć, że soft law prawa bankowego, jakim jest rekomendacja $S$, podlega stopniowej normatywizacji, bowiem praktyki wzorcowego zachowania się banków wyrażone w tej rekomendacji, służące przecież również ochronie klienta tego rynku, otrzymały głęboką ustawową regulację. Wydaje się, że w odniesieniu do innych treści, które mają lub mogą wykazywać charakter makroostrożnościowy, w prawie rynku finansowego akcent regulacyjny zostanie wzmocniony i w sposób zdecydowany położony jednak na uszczegółowione i precyzyjne rozwiązania ustawowe.

Z kolei w odniesieniu do nadzoru nad działalnością pośredników hipotecznych i agentów można wskazać, że regulacja ustawowa dobrze wpisuje się we współczesną tendencję regulacyjną w zakresie nadzoru nad rynkiem finansowym, polegającą również na objęciu nowych obszarów nadzorem lub intensyfikacji nadzoru, zwłaszcza w dziedzinach, które moga generować ryzyko systemowe, a takim obszarem jest rynek kredytów hipotecznych. Trzeba też podkreślić, że występowanie zjawiska interferencji norm prawa publicznego i prawa prywatnego w obszarze analizowanej ustawy jest widoczne zarówno w odniesieniu do norm dotyczących ochrony klienta, bowiem na banki nakładane są dodatkowe obowiązki wiązane $\mathrm{z}$ zapewnieniem tej ochrony i na dodatek określany jest precyzyjnie sposób ich wykonania (i to zarówno w ustawie, jak i we wcześniejszej rekomendacji S), jak i w odniesieniu do postanowień nadzorczych, gdyż - słusznie - nadzorowi poddano bardzo ważny fragment działalności realizowanej przez pośredników 
kredytowych i agentów. Analiza postanowień ustawy o kredycie hipotecznym oraz treści zawartych $\mathrm{w}$ rekomendacji S, odnoszona także do celów ustawy makroostrożnościowej, pozwala na sformułowanie wnios$\mathrm{ku}$, że przyjęta nowa ustawa o kredycie hipotecznym, odczytywana w świetle założeń ustawy makroostrożnościowej, stanowi zapowiedź nowego systemowego podejścia do aktywności podejmowanych na rynku kredytów hipotecznych, a rzetelnie realizowana może przyczyniać się do minimalizowania wystąpienia sytuacji kryzysowych. Warto podkreślić, co pokazuje doświadczenie kryzysowe, że źródłami, mogącymi m.in. mieć makroostrożnościowe znaczenie, jest właśnie nadzór nad pośrednikami i agentami hipotecznymi oraz objęcie klienta rynku usług hipotecznych taką ochrona, która pozwoli na ograniczenie ryzyka systemowego.

\section{PROVISIONS OF THE ACT OF 23 MARCH 2017 ON MORTGAGE CREDIT AND SUPERVISION OF MORTGAGE CREDIT INTERMEDIARIES AND AGENTS AND RECOMMENDATION S OF THE POLISH FINANCIAL SUPERVISION AUTHORITY VERSUS THE PREVENTION OF MORTGAGE BANKING CRISES}

\section{S u m mary}

On 23 March 2017, the Act on mortgage credit and supervision of mortgage credit intermediaries and agents was passed, which implements Directive 2014/17/EU of the European Parliament and of the Council of 4 February 2014 on credit agreements for consumers relating to residential immovable property and amending Directives 2008/48/EC and 2013/36/EU and Regulation (EU) No 1093/2010. The Act on mortgage credit under examination contains consumer protection standards for mortgage banking services, which can pursue objectives and perform macro-prudential functions in the financial system. The Act also provides for the supervision of mortgage intermediaries and their agents providing mortgage credit services, rightly considering that since this is a matter of macro-prudential substance and capable of having an impact on financial stability, a comprehensive supervision of the activities of mortgage intermediaries and agents is justified.

The aim of the study is to (i) examine the provisions of the Act on mortgage credit from the perspective of its macro-prudential content; (ii) reconstruct this potentially macro-prudential content; (iii) assess the regulatory arrangements for credit intermediaries and residential immovable property agents adopted by the Act; and (iv) address the issue, relevant to the theory of financial market law, of the interference between private and public law rules in terms of their macro-prudential content and macro-prudential policy. It is also intended to perform a comparison of the provisions of the Act on mortgage credit with selected recommendations 
of Recommendation S of the Financial Supervision in order to assess their macro-prudential nature and the appropriateness of the regulatory solutions adopted by means of an act or by means of national soft banking law to which Recommendation $\mathrm{S}$ belongs.

Keywords: macro-prudential matter - mortgage credit - macro-prudential supervision - Act on mortgage credit - consumer protection in the mortgage banking market 